\title{
Android-Based Learning Media Development on Fraction Material
}

\author{
Sufah Iliya Manazila ${ }^{1}$, Hikmah Supriyati ${ }^{2}$ \\ ${ }^{1}$ Mathematics Education Department, ${ }^{2}$ Biology Education Department Faculty of Science and Technology UIN Sunan Kalijaga \\ Jl. Marsda Adisucipto No. 155281 Yogyakarta, Indonesia. Tel. + 62-274-540971, Fax. + 62-274-519739 \\ 1Email: sufahiliyamanazila624@gmail.com
}

\begin{abstract}
This research aims to find out how to Android-based learning media develop on fraction material, and find out the quality of products that have been developed. This study uses 4D development methods, namely, (Define, Design, Development, Dissemination). Data collection uses validation and student response methods which are then analyzed descriptively qualitative. The results of this study are in the form of Android-based learning media with the APK extension. Validation test shows that the android-based learning media development on fractions material, theoreticaly is $86.23 \%$ (Category: Very Good) and empirically with a percentage of $86.67 \%$ (Category: Very Good).
\end{abstract}

Keywords: Android, Fraction, Learning media

\section{INTRODUCTION}

Fractions are one of the most important mathematics materials to be taught. Fractional material is the basic material used to study other material. Fractions are often used in everyday life, but there are still many students who still have difficulty understanding the fraction numbers (Rahmawati: 2017). The reasons are because learning is dominated by formal ways so that it does not support students' understanding the concept of fractions (Zabeta, et al: 2015). The approach conduct by the teacher mostly only conveyed with package book and did not accommodate the students' abilities (Noer, 200: 41). Learning like this causes students difficulty in understanding concepts and less motivated to learn mathematics.

From these problems, a learning innovation is needed. One alternative that can be done is to create learning media. Sadiman (2006: 7) suggests that the media is everything that can be used to channel messages from the sender to the recipient so that it can stimulate thoughts, feelings, interests and students attention in such a way that the learning process occurs. Learning media is a means so that students are not bored in lessons. The biggest effect that is expected is to be able motivate students and facilitate them in receiving material (Fanny: 2013). The forms of learning media are increasingly varied along with the development of information technology. One that is being massively used in Indonesia is an Android-based learning media. This is influenced by the increasing number of Android-based smartfone users, especially among students.

Android-based learning media can be used as an independent learning media for students both at school and outside school. The media can be used by educators as a medium of learning in the teaching and learning process (Joko et al: 2018). Based on the description above, the researcher try to develop and find out the quality of the Android-based learning media, which is a game that contains fractional material. Learning media is made so that students know more about the concept of fractions and can be motivate students to learn.

\section{MATERIALS AND METHOD}

The first research is develop an android application on fractional material with the 4D method namely Define, Design, Development, Dissemination (Sugiyono, 2017). The results of the development Android application will be analyzed descriptively. The second research was carried out by testing the quality of the android application to several experts namely material experts, media experts, Peer reviewers and mathematics teachers. In addition, questionnaires were also conducted to find out the students' response to the android application. The second study used qualitative and quantitative descriptive data analysis. This is done to determine the feasibility and ideals of the development of android application of fractional material as a learning source (Widoyoko, 2012). In addition, qualitative and quantitative data will be used as the basis for improving android applications on fraction material.

\section{RESULTS AND DISCUSSION}

\section{Android-Based Learning Media Development on Fractional Material}

This research produced an application with the APK (application package) extension. The process of making this application uses Corel Draw X7 to create a design. Whereas to make the page design into an application form that can be installed on a smartphone using 
Construct 2 application. The manufacturing stages are as follows:

1. Define.

This stage aims to define the needs of mathematics learning. Activities conduct in this stage are problem analysis and student analysis. In problem analysis, researchers looking for information about difficulties in understanding mathematical concepts. One of the difficulties experienced is the fractional material. Therefore, the learning media developed are fractions. The next activity is an analysis of the current condition of students. Based on the analysis of students, the developed learning media was packaged in an educational game that was accessed through an Android smartphone.

2. Design

First stage that is conduct in the design is to make an overview of the game to be developed. Next is to make a prototype. Prototype is the initial design before the game was made. the purpose of making a prototype is that the game is made more organized. After making a prototype, the next step is designing the game. Game design is done using Corel Draw X7.

3. Development

Activities conduct in this stage are giving interfaces, coding, compilation and configuration. The following is an explanation of the development stage

4. Providing interface

Interface delivery is done using Construct 2 Software. Here are some interfaces in the game, namely:

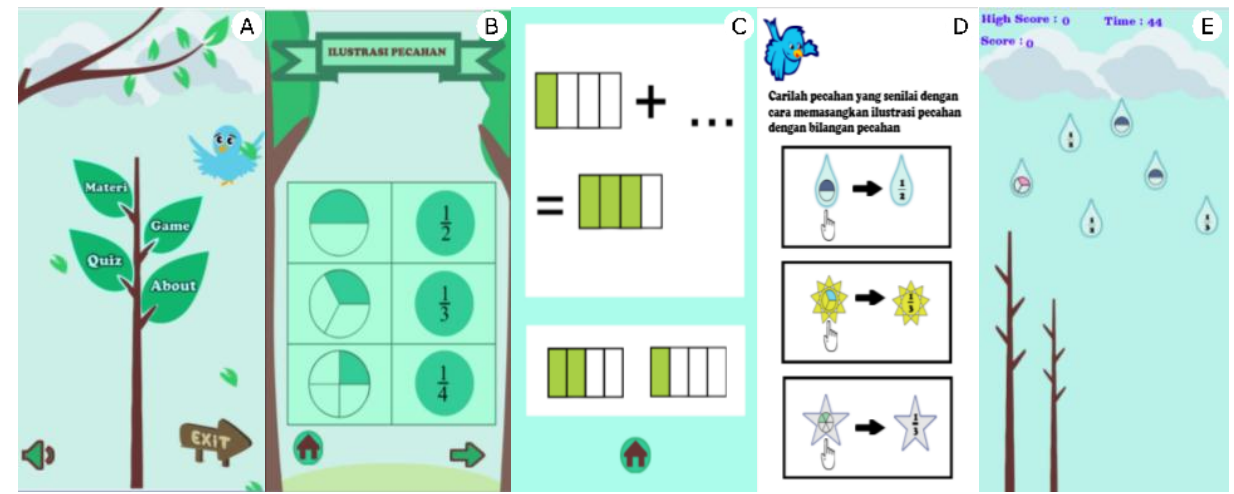

Figure 1. Several interfaces in the game i.e: (A) Main menu, (B) Material, (C) Quiz, (D) Game instruction, (E) Game display.

\section{Coding}

At this stage the things that conduct are giving behavior and events to the existing objects.

6. Compilation and Configuration

At this stage the thing to do is to collect html 5based programs and rearrange them into a new program that is able to run on android using Adobe Phonegap.

\section{Feasibility Test of Android Applications on Fractional Material}

The media that has been developed is then tested for quality. This is done to find out the quality of products developed through the assessment of experts. The theoretical feasibility assessed includes several aspects, namely aspects (material, evaluation, language, design, presentation of learning, application operation, and implementation). The results of the percentage aspects assessment of experts are as follows:

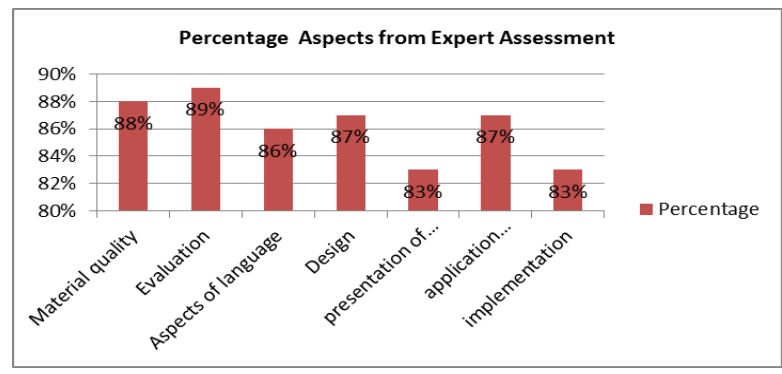

Figure 2. Percentage aspects from expert assessment.

Validation results of android-based learning media on the criteria of material aspects is $88 \%$ (Category: Very Good), this is because in composition is adjusted with the material and KD to be achieved. According to Ibrahim (2010) one of the criteria in making learning media must be adapted to goals and learning. Evaluation on aspects of evaluation (89\%) (Category: Very Good), in this section researchers package evaluations with various illustrations and images so 
that the appearance is more attractive and makes it easier for students to understand the material. The results research on the aspect of language got a percentage value of (86\%) (Category: Very Good), This is because researchers use language that is easily understood by children at the junior high school level, so it is expected to help students understand the material. According to Diknas (2004) in Prastowo (2011) the use of language that is appropriate to the level of child development will motivate hard learning and intelligent learning.

Design aspect (87\%) (Category: Very Good), this aspect has a quite good assessment because the developed android application has an attractive appearance and can stimulate students to use the application. Ministry of National Education (2004) states that in the preparation of learning resources it is very important to attention attractiveness and ease of reading. aspect of presenting learning (83\%) (Category: Good), the presentation of an interesting android application is one aspect that can foster student interest and motivation in learning. This is in accordance with Prastowo (2012) which states that learning resources must include several requirements, namely: practical, easy to obtain, flexible, in accordance with goals, and can motivate students. The aspect of implementation gets the lowest score from the other aspects $(83 \%)$ (Category: Good), so the researchers make improvements according to suggestions. The results of assessment from the experts as a whole are as follows:

Table 1. Validation results of android applications on fractional material.

\begin{tabular}{|c|c|c|c|c|c|}
\hline No. & Evaluator & Assessment Item & X (Total Score) & $\mathbf{P} \%$ & Quality \\
\hline 1 & Media Expert & 20 & 83 & $83 \%$ & Good \\
\hline 2 & Material Expert & 12 & 53 & $88,33 \%$ & Very Good \\
\hline 3 & Peer reviewer & 28 & 124,7 & $89,07 \%$ & Very Good \\
\hline \multirow[t]{2}{*}{4} & Math Teacher & 16 & 67 & $83,75 \%$ & Good \\
\hline & Total & 76 & 335,7 & $86,23 \%$ & Very Good \\
\hline
\end{tabular}

The results of research that has been done, it can be seen as a whole that the Android-based learning media on fraction material is Very Good. This shows that the Android-based learning media is theoretically feasible and has fulfilled all aspects that have been determined.

After the Android application media was assessed theoriticaly feasibility, the media was tested on 10 students of Junior High School Muhammadiyah 3 Depok Yogyakarta. This is done to find out the students' response to Android-based learning media. The components tested include: (ease of using the Android application, student interest in using the Android application, presentation of material, and the effect of the Android application on motivation, understanding and satisfaction using the Android application). Results Assessment of student responses can be seen in the table below:

Table 2. Assessment of student response to android applications.

\begin{tabular}{llllll}
\hline No. & Component & Assessment Item & Total Score & P (\%) & Quality \\
\hline 1 & $\begin{array}{l}\text { Ease of operating an Android } \\
\text { application }\end{array}$ & 2 & 9,6 & $96 \%$ & Very Good \\
2 & $\begin{array}{l}\text { Student interest in using the } \\
\text { Android application }\end{array}$ & 2 & 8,4 & $84 \%$ & Good \\
3 & $\begin{array}{l}\text { Presentation of Material } \\
\text { The effect of the game on } \\
\text { students' motivation }\end{array}$ & 2 & 8,6 & $86 \%$ & Very Good \\
5 & $\begin{array}{l}\text { The effect of the game on } \\
\text { students' understanding }\end{array}$ & 2 & 8,2 & $82 \%$ & Good \\
6 & $\begin{array}{l}\text { Student satisfaction using the } \\
\text { Android application }\end{array}$ & 2 & 8,8 & $88 \%$ & Very Good \\
Total & & $\mathbf{1 2}$ & 8,4 & $\mathbf{5 2}$ & $\mathbf{8 6 , 6 7 \%}$ \\
\hline
\end{tabular}

Based on research that has been done, that androidbased learning media get a positive response from students with an empirical feasibility percentage of $86.67 \%$ (category: very good). In this criterion the percentage results are quite high because all this time students only learn to use textbooks so learning using android-based media is a new experience for students. According to Muyaroah and Mega (2017) stated that 
learning using an android application is very effective. This is because the system designed involves students actively and independently in learning.

\section{CONCLUSIONS}

Based on the results of the research that has been carried out, the following conclusions can be drawn:

1. This research resulted in the development of android-based media products that contained fractional material. The process of developing this application through the 4D development stage, namely define, design, development, and dissemination. This product is designed using Corel Draw X7 and the Construct 2 Application.

2. The trial of the development of Android-based media on fraction material obtained a theoretical percentage of $86.23 \%$ (Category: Very Good) and empirically with a percentage of $86.67 \%$ (Category: Very Good). The results percentage of material experts were $88.33 \%$ (Category: Very Good), media experts $83 \%$ (Category: Good), $89.07 \%$ peer reviewers (Category: Very Good), and mathematics teachers $83.75 \%$ (Category: Good).

\section{REFERENCES}

Departemen Pendidikan Nasional. 2004. Kurikulum 2004. Jakarta: Media Makmur Maju Mandiri

Fanny, Arif Mahya, Siti Partini Suardiman. (2013). Pengembangan Multimedia Interaktif Untuk Mata Pelajaran Ilmu Pengetahuan Sosial (IPS) Sekolah Dasar Kelas V. Jurnal Prima Edukasia, Vol: I No. 1.

Ibrahim, M. 2010. Dasar-dasar Proses Belajar Mengajar. Surabaya: Unesa University Press

Joko Kuswanto, Ferri Radiansah. (2018). Media Pembelajaran Berbasis Android Pada Mata Pelajaran Sistem Operasi Jaringan Kelas XI. Jurnal Media Infotama Vol. 14 No. 1.

Mewa Zabeta, Yusuf Hartono, Ratu Ilma Indra Putri. (2015). Desain Pembelajaran Materi Pecahan Menggunakan Pendekatan PMRI di Kelas VII. Jurnal Beta Vol. 8 No. 1.

Muyaroah, Siti, Mega Fajartia. 2017. Pengembangan Media Pembelajaran Berbasis Android dengan Menggunakan Aplikasi Adobe Flash CS6 pada Mata Pelajaran Biologi. Innovative Journal of Curriculum and Educational Technology IJCET 6 (2) (2017)

Noer Hastuti Sri, 2007. Pembelajaran Open Ended untuk Meningkatkan Kemampuan Pemecahan Masalah Matematik dan Kemampuan Berfikir Kreatif. Tesis Sps UPI: Tidak Diterbitkan

Prastowo, Andi. 2011. Panduan Keratif Membuat Bahan Ajar Inovatif. Yogyakarta: Diva Press

Rahmawati. (2017). Desain Pembelajaran Penjumlahan dan Pengurangan Pecahan dengan Menggunakan Timbangan Siswa Kelas IV. Jurnal Pendidikan Matematika, Vol: 11 No. 1.

Sugiyono. (2017). Metode Penelitian dan Pengembangan Research a Development. Bandung: Alfabeta

Widoyoko, Putro. 2012. Evaluasi Program Pembelajaran. Yogyakarta : Pustaka Pelajar

http://eprints.uny.ac.id/9668/3/bab\%202\%20-\%2008205244010.pdf 